\title{
Energy and Economic Impacts of U.S. Federal Energy and Water Conservation Standards Adopted From 1987 Through 2010
}

\author{
Principal Authors \\ Stephen Meyers, Alison Williams and Peter Chan \\ Environmental Energy Technologies Division \\ Project Contributors \\ Greg Rosenquist, Helcio Blum, Barbara Atkinson, Sanaee Iyama, Jie Gu, Maithili Iyer \\ Environmental Energy Technologies Division
}

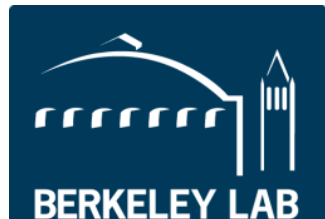

Lawrence Berkeley National Laboratory

Lawrence Berkeley National Laboratory One Cyclotron Road

Berkeley, CA 94720

December 2011

The work described in this report was funded by the U.S. Department of Energy's Office of Energy Efficiency and Renewable Energy, Building Technologies Program under Contract No. DE-AC02$05 \mathrm{CH} 11231$. 


\section{Disclaimer}

This document was prepared as an account of work sponsored by the United States Government. While this document is believed to contain correct information, neither the United States Government nor any agency thereof, nor the Regents of the University of California, nor any of their employees, makes any warranty, express or implied, or assumes any legal responsibility for the accuracy, completeness, or usefulness of any information, apparatus, product, or process disclosed, or represents that its use would not infringe privately owned rights. Reference herein to any specific commercial product, process, or service by its trade name, trademark, manufacturer, or otherwise, does not necessarily constitute or imply its endorsement, recommendation, or favoring by the United States Government or any agency thereof, or the Regents of the University of California. The views and opinions of authors expressed herein do not necessarily state or reflect those of the United States Government or any agency thereof or the Regents of the University of California.

Lawrence Berkeley National Laboratory is an equal opportunity employer. 


\section{Acknowledgements}

The work described in this report was funded by the U.S. Department of Energy's Office of Energy Efficiency and Renewable Energy, Building Technologies Program under Contract No. DE-ACO2$05 \mathrm{CH} 11231$.

The authors acknowledge the contributions of Michael McCabe of the U.S. Department of Energy and the editing of Mary James of Berkeley Lab. 


\section{Table of Contents}

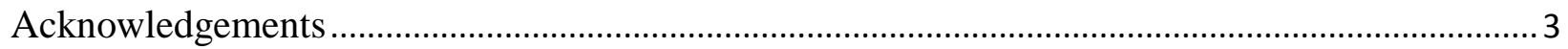

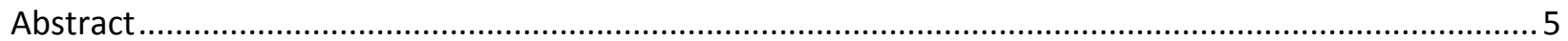

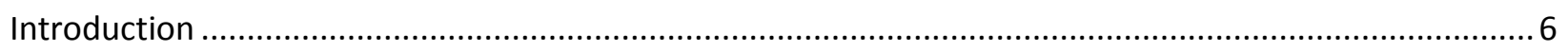

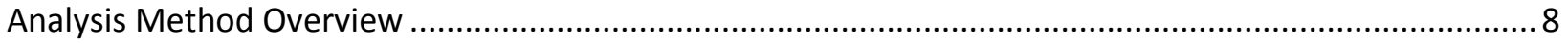

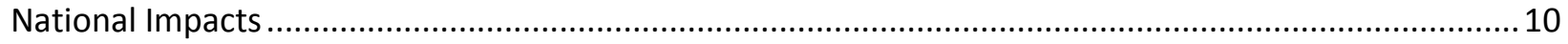

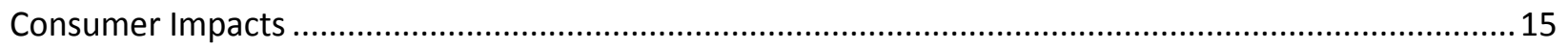

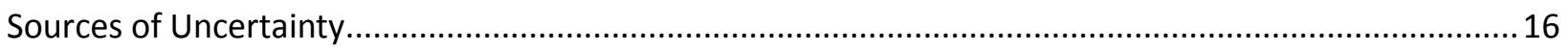

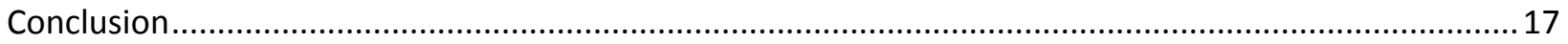

Appendix A: Methods for Estimating National Impacts from Standards ................................................ 18

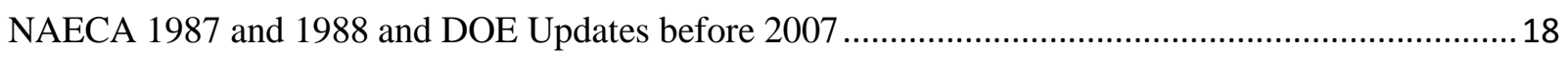

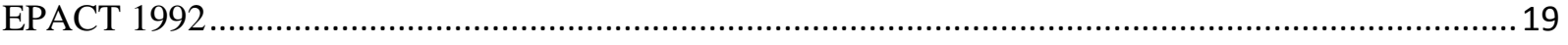

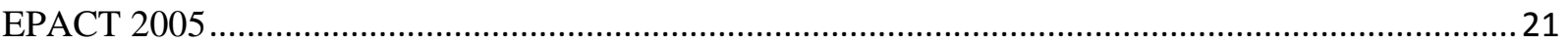

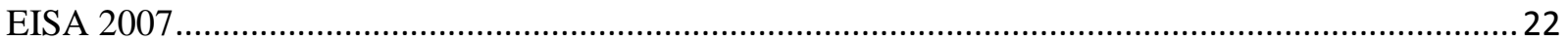

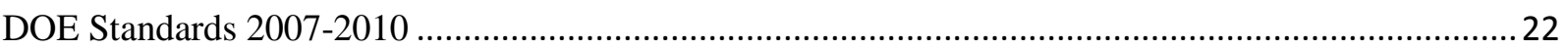

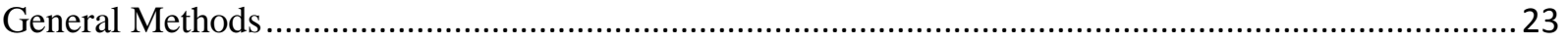

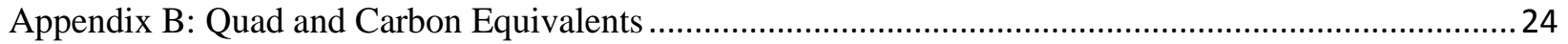




\begin{abstract}
This paper presents estimates of the key impacts of the energy and water conservation standards that have been adopted from 1987 through 2010. The standards covered include those set by legislation as well as standards adopted by DOE through rulemaking. We estimate that energy efficiency standards for consumer products and certain commercial and industrial equipment that have been adopted from 1987 through 2010 saved 3.0 quads in 2010, have had a cumulative energy savings of 25.9 quads through 2010 and will achieve cumulative energy savings of 158 quads over the period 1990-2070. Thus, the majority of the savings are still to come as products subject to standards enter the stock. Furthermore, the standards will have a cumulative net present value (NPV) of consumer benefit of between $\$ 851$ billion and $\$ 1,103$ billion, using 7 percent and 3 percent discount rates, respectively. In addition, we estimate the water conservation standards, together with those energy conservation standards that also save water, saved residential consumers 1.5 trillion gallons of water in 2010, have had cumulative water savings of 11.7 trillion gallons through 2010, and will achieve cumulative water savings by 2040 of 51.4 trillion gallons.
\end{abstract}




\section{Introduction}

The energy conservation program for consumer products and certain commercial and industrial products was established by the Energy Policy and Conservation Act of 1975 (EPCA). EPCA established a program consisting of test procedures, labeling, and energy conservation targets for 19 types of consumer products. The National Energy Conservation Policy Act of 1978 amended EPCA by replacing the energy conservation targets program and directing that energy conservation standards be set for the covered consumer products. With the passage of the National Appliance Energy Conservation Act (NAECA) in 1987, EPCA was further amended to establish the first national energy conservation standards for consumer products. Subsequent amendments in 1988, 1992, 2005, and 2007 further expanded the scope of coverage to include additional consumer products, certain commercial and industrial equipment, as well as water conservation standards for residential and commercial products. EPCA, as amended, requires the Department of Energy (DOE) to update or establish standards at levels that "achieve the maximum improvement in energy [or water] efficiency ... which the Secretary determines is technologically feasible and economically justified." EPCA defines "economically justified" standards as those for which benefits exceed the costs, given a number of factors, including impacts on consumers and manufacturers and the nation's need to save energy or water.

This paper presents estimates of the key impacts of the energy and water conservation standards that have been adopted from 1987 through 2010. The standards covered include those set by legislation as well as standards adopted by DOE through rulemaking. The estimates cover both historic and projected impacts of these standards. The impacts cover primary energy savings and water savings, net present value of consumer benefits, and estimated reductions in $\mathrm{CO}_{2}$ emissions.

Table 1 lists products covered by standards, the year(s) compliance was or will be required, and the legislation that initially authorized each standard. 
Table 1. Federal Energy and Water Conservation Standards for Appliances and Equipment Adopted From 1987 Through 2010

\begin{tabular}{|c|c|c|}
\hline Product & $\begin{array}{c}\text { Compliance Date for } \\
\text { Original Standard and } \\
\text { Updates }\end{array}$ & $\begin{array}{l}\text { Authorizing } \\
\text { Legislation* }\end{array}$ \\
\hline \multicolumn{3}{|l|}{ RESIDENTIAL } \\
\hline Clothes Washers $^{+}$ & $1988,1994,2004 / 2007$ & NAECA 1987 \\
\hline Clothes Dryers & 1988,1994 & NAECA 1987 \\
\hline Dishwashers $^{+}$ & $1988,1994,2010$ & NAECA 1987 \\
\hline Refrigerators and Refrigerator-Freezers & $1990,1993,2001$ & NAECA 1987 \\
\hline Freezers & $1990,1993,2001$ & NAECA 1987 \\
\hline Room Air Conditioners & 1990,2000 & NAECA 1987 \\
\hline $\begin{array}{l}\text { Central Air Conditioners and Central Air } \\
\text { Conditioning Heat Pumps }\end{array}$ & 1992/1993, 2006 & NAECA 1987 \\
\hline Water Heaters & $1990,2004,2015$ & NAECA 1987 \\
\hline Furnaces & 1992 & NAECA 1987 \\
\hline Furnace Fans & Authorized & EPACT 2005 \\
\hline Boilers & 1992,2012 & NAECA 1987 \\
\hline Direct Heating Equipment & 1990,2013 & NAECA 1987 \\
\hline Cooking Products & 1990,2012 & NAECA 1987 \\
\hline Pool Heaters & 1990,2013 & NAECA 1987 \\
\hline Ceiling Fans and Ceiling Fan Light Kits & 2007 & EPACT 2005 \\
\hline Torchieres & 2006 & EPACT 2005 \\
\hline Dehumidifiers & 2007,2012 & EPACT 2005 \\
\hline External Power Supplies & 2008 & EISA 2007 \\
\hline Battery Chargers & Authorized & EPACT 2005 \\
\hline Television Sets & Authorized & NAECA 1987 \\
\hline Standby Power & Authorized & EISA 2007 \\
\hline \multicolumn{3}{|l|}{ COMMERCIAL \& INDUSTRIAL } \\
\hline Electric Motors & 1997,2010 & EPACT 1992 \\
\hline Warm Air Furnaces & 1994 & EPACT 1992 \\
\hline Packaged Boilers & 1994 & EPACT 1992 \\
\hline Air Conditioners and Heat Pumps & $\begin{array}{l}\text { 1994/1995, 2003/2004, } \\
2010,2012\end{array}$ & EPACT 1992 \\
\hline $\begin{array}{l}\text { Water Heaters, Hot Water Supply Boilers and } \\
\text { Unfired Hot Water Storage Tanks }\end{array}$ & 1994,2004 & EPACT 1992 \\
\hline Distribution Transformers & 2007,2010 & $\begin{array}{l}\text { EPACT 1992, EPACT } \\
2005\end{array}$ \\
\hline Refrigerators, Refrigerator-Freezers and Freezers & 2010,2012 & EPACT 2005 \\
\hline Automatic Ice Makers & 2010 & EPACT 2005 \\
\hline Clothes Washers $^{+}$ & 2007 & EPACT 2005 \\
\hline Unit Heaters & 2008 & EPACT 2005 \\
\hline Refrigerated Beverage Vending Machines & 2012 & EPACT 2005 \\
\hline Walk-in Coolers and Walk-in Freezers & 2009 & EISA 2007 \\
\hline
\end{tabular}




\begin{tabular}{|c|c|c|}
\hline Fluorescent Lamp Ballasts & $1990,2005 / 2010$ & NAECA 1988 \\
\hline $\begin{array}{l}\text { General Service Fluorescent Lamps and } \\
\text { Incandescent Reflector Lamps }\end{array}$ & $1995,2008,2012$ & $\begin{array}{l}\text { EPACT 1992, EISA } \\
2007\end{array}$ \\
\hline Medium Base Compact Fluorescent Lamps & 2006 & EPACT 2005 \\
\hline Illuminated Exit Signs & 2006 & EPACT 2005 \\
\hline Traffic Signal Modules and Pedestrian Modules & 2006 & EPACT 2005 \\
\hline Mercury Vapor Lamp Ballasts & 2008 & EPACT 2005 \\
\hline Metal Halide Lamp Ballasts and Fixtures & 2009 & EISA 2007 \\
\hline $\begin{array}{l}\text { General Service Incandescent Lamps, } \\
\text { Intermediate Base Incandescent Lamps and } \\
\text { Candelabra Base Incandescent Lamps }\end{array}$ & $2012 / 2014 \& 2020$ & EISA 2007 \\
\hline \multicolumn{3}{|l|}{ PLUMBING PRODUCTS } \\
\hline Faucets $^{++}$ & 1994 & EPACT 1992 \\
\hline Showerheads $^{++}$ & 1994 & EPACT 1992 \\
\hline Water Closets $^{++}$ & $1994 / 1997$ & EPACT 1992 \\
\hline Urinals $^{++}$ & $1994 / 1997$ & EPACT 1992 \\
\hline Pre-rinse Spray Valves ${ }^{++}$ & 2007 & EPACT 2005 \\
\hline \multicolumn{3}{|c|}{$\begin{array}{l}\text { * The Energy Policy and Conservation Act of } 1975 \text { was amended to set energy or water conservation standards by } \\
\text { the National Appliance Energy Conservation Act (NAECA 1987), the National Appliance Energy Conservation } \\
\text { Amendments of } 1988 \text { (NAECA 1988), the Energy Policy Act of } 1992 \text { (EPACT 1992), the Energy Policy Act of } \\
2005 \text { (EPACT 2005), and the Energy Independence and Security Act of } 2007 \text { (EISA 2007). }\end{array}$} \\
\hline \multicolumn{3}{|c|}{$\begin{array}{l}{ }^{+} \text {Water and energy conservation standard } \\
{ }^{++} \text {Water conservation standard }\end{array}$} \\
\hline
\end{tabular}

\section{Analysis Method Overview}

Different analytical methods were used for four sets of standards. For NAECA 1987 and NAECA 1988 standards and DOE updates of those standards issued before 2007, we utilized the analyses conducted by Lawrence Berkeley National Laboratory (LBNL) in 2007-2008. ${ }^{1}$ For EPACT 1992 standards, we developed new estimates for this study. For EPACT 2005 standards, we reviewed and utilized an analysis conducted by Nadel et $a .^{2}$ and added information from other DOE analyses where available. For most of the EISA 2007 standards, we drew upon an analysis conducted by DOE. ${ }^{3}$ For the other EISA 2007 standards, ${ }^{a}$ we used unpublished national impact analyses that were prepared by LBNL for DOE. For standards adopted by DOE in 20072010, we drew on the national impact analyses performed for the rulemakings for each of the standards and adapted the results for the framework of this study. Appendix A further describes the use of the above sources in this study.

It is important to note that the analyses performed for the rulemakings for each of the standards were highly detailed and were carefully reviewed by stakeholders. All of the other sources used for this study were much less detailed in their approach and less extensively reviewed.

${ }^{\mathrm{a}}$ Dishwashers, residential boilers and dehumidifiers. 
The sources used for this study vary in how they characterized the base case (i.e., assuming no new or amended standards) against which impacts of standards were measured. The LBNL analysis of the NAECA standards and DOE updates of those standards before 2007 estimated a dynamic base case in which the energy efficiency of the products improves somewhat even without standards. The analyses performed for DOE's rulemakings also generally consider how the market might change in the absence of new or amended standards. In contrast, the analyses used for EPACT 1992, EPACT 2005, and EISA 2007 standards used simple assumptions (e.g., no change in efficiency) regarding the base case.

We focused on three key impacts associated with standards: (1) primary energy savings; (2) additional installed costs; and (3) operating cost savings. Operating cost savings primarily consist of energy cost savings. For standards that save water, we also included water cost savings where possible. In some cases (primarily the DOE rulemakings in 2007-2010), the operating cost savings also include changes in maintenance and repair costs associated with the standards.

From (2) and (3) we derived net cost or savings for each year. We also estimated reductions in $\mathrm{CO}_{2}$ emissions associated with the standards using the annual primary energy savings and annual average $\mathrm{CO}_{2}$ emissions factors for the electricity generation sector and for natural gas.

For each standard we developed a time series of annual impacts, with economic impacts expressed in 2010 dollars. For the NAECA standards and DOE updates of those standards before 2007, and for standards adopted by DOE in 2007-2010, we estimated annual impacts for each standard for 30 years worth of shipments, which is the convention that DOE uses in its rulemaking analyses. For most of the other standards, for which the base case often assumes no change in efficiency, we used a shorter period of shipments as a way of compensating for the lack of a dynamic base case, which might tend to overstate the savings from standards. We estimated annual energy savings and operating cost savings until products installed in the final year are retired from the stock. Retirement is based on the average lifetime for each product.

Using the annual economic impacts, we derived a net present value by discounting future impacts to the present (defined as 2010 for purposes of analysis). For economic impacts occurring after 2010, we used discount rates of $3 \%$ and $7 \%$, which are the rates used by DOE in its rulemaking analyses, in accordance with guidance from the Office of Management and Budget to Federal agencies on the development of regulatory analysis. ${ }^{4}$ For economic impacts occurring before 2010, we derived estimates of their present value using interest rates of $3 \%$ and $7 \%$. This approach reflects the view that the present value of the past stream of benefits should reflect the returns to those "profits" had they been invested elsewhere in the economy. 
We estimated a monetary value of the reductions in $\mathrm{CO}_{2}$ emissions using the mid-range series for the global Social Cost of Carbon (SCC) developed by a Federal interagency process. ${ }^{b}$ This series has a value of $\$ 22.3$ per metric ton in 2010 and increases at 3 percent per year.

\section{National Impacts ${ }^{c}$}

In 2010, the standards saved an estimated 3.0 quads of primary energy, which is equivalent to $3 \%$ of total U.S. energy consumption. The net consumer savings were $\$ 27$ billion.

As shown in Table 2, the cumulative primary energy savings through 2010 amount to 25.9 quads. The cumulative consumer NPV through 2010, which equals the operating cost savings minus the additional product costs associated with standards, is between $\$ 270$ billion and $\$ 341$ billion.

Over the entire time period considered (1990-2070), the cumulative primary energy savings total 157 quads and the cumulative consumer NPV is between $\$ 841$ billion and $\$ 1,094$ billion (Table 3). Residential products account for more than half of the total cumulative primary energy savings. In addition to energy cost savings from energy conservation standards, the consumer NPV includes water cost savings from those standards that affect both energy and water use (such as standards on clothes washers), as well as energy cost savings from water conservation standards that save hot water (i.e., standards on faucets and showerheads).

The cumulative energy savings achieved through 2010 are only 16 percent of the total cumulative energy savings. Thus, most of the savings from standards already adopted will occur in the future. Furthermore, future savings will grow as new standards are adopted, such as the amended standards for residential refrigeration products, furnaces, air conditioners and heat pumps, clothes dryers, and room air conditioners that have been adopted by DOE in 2011.

\footnotetext{
${ }^{\mathrm{b}}$ For details on the SCC values, see appendix 16-A of the Technical Support Document for the final rule for residential refrigeration products.

http://www1.eere.energy.gov/buildings/appliance_standards/pdfs/refrig_finalrule_tsd.pdf

${ }^{\mathrm{c}}$ Additional results, including impacts by each standard, are presented in the Excel spreadsheet used to calculate the impacts, which may be found at the page for this report at: http://efficiency.lbl.gov/bibliography/
} 
Table 2. Cumulative Primary Energy Savings and Cumulative Consumer NPV Through 2010 for all Standards

\begin{tabular}{|lcccc|}
\hline $\begin{array}{l}\text { Source of } \\
\text { Standards }\end{array}$ & $\begin{array}{c}\text { Primary } \\
\text { energy } \\
\text { savings } \\
\text { (quads) }\end{array}$ & $\begin{array}{c}\text { Share of } \\
\text { primary } \\
\text { energy } \\
\text { savings }\end{array}$ & $\begin{array}{c}\text { Cumulative } \\
\text { NPV (billion } \\
\mathbf{2 0 1 0} \$)^{*}\end{array}$ & Share of NPV \\
\hline Residential & 15.1 & $58 \%$ & $\$ 96-\$ 121$ & $35-36 \%$ \\
\hline $\begin{array}{l}\text { Commercial \& } \\
\text { Industrial }\end{array}$ & 3.0 & $12 \%$ & $\$ 17-\$ 20$ & $6 \%$ \\
\hline Lighting Products & 5.0 & $19 \%$ & $\$ 46-\$ 61$ & $17-18 \%$ \\
\hline $\begin{array}{l}\text { Plumbing } \\
\text { Products }\end{array}$ & 2.8 & $11 \%$ & $\$ 111-\$ 139$ & $41 \%$ \\
\hline Total & 25.9 & $100 \%$ & $\$ 270-\$ 341$ & $100 \%$ \\
\hline
\end{tabular}

* The lower value refers to the NPV using $7 \%$ discount rate, while the higher value refers to the NPV using $3 \%$ discount rate.

Table 3. Cumulative Primary Energy Savings and Cumulative Consumer NPV for all Standards

\begin{tabular}{|lcccc|}
\hline $\begin{array}{l}\text { Source of } \\
\text { Standards }\end{array}$ & $\begin{array}{c}\text { Cumulative } \\
\text { primary } \\
\text { energy } \\
\text { savings } \\
\text { (quads) }\end{array}$ & $\begin{array}{c}\text { Share of total } \\
\text { cumulative } \\
\text { primary } \\
\text { energy } \\
\text { savings }\end{array}$ & $\begin{array}{c}\text { Cumulative } \\
\text { NPV (billion } \\
\mathbf{2 0 1 0} \$)^{*}\end{array}$ & $\begin{array}{c}\text { Share of total } \\
\text { cumulative } \\
\text { NPV }\end{array}$ \\
\hline Residential & 84.5 & $54 \%$ & $\$ 376-\$ 521$ & $44-47 \%$ \\
\hline $\begin{array}{l}\text { Commercial \& } \\
\text { Industrial }\end{array}$ & 28.0 & $18 \%$ & $\$ 70-\$ 112$ & $7-10 \%$ \\
\hline Lighting Products & 37.1 & $23 \%$ & $\$ 151-\$ 205$ & $18-19 \%$ \\
\hline $\begin{array}{l}\text { Plumbing } \\
\text { Products }\end{array}$ & 8.3 & $5 \%$ & $\$ 254-\$ 264$ & $24-30 \%$ \\
\hline Total & 157.9 & $100 \%$ & $\$ 851-\$ 1,103$ & $100 \%$ \\
\hline
\end{tabular}

* The lower value refers to the NPV using 7\% discount rate, while the higher value refers to the NPV using $3 \%$ discount rate.

As shown in Table 4, standards set by legislation account for 72 percent of cumulative energy savings through 2010, and DOE rulemakings account for 28 percent. Considering the total cumulative primary energy savings (Table 5), standards set by legislation account for 52 percent of total cumulative primary energy savings and $62 \%-71 \%$ of the total cumulative consumer NPV (depending on which discount rate is used). Standards set by DOE rulemakings account for $48 \%$ of total cumulative primary energy savings and $29 \%-38 \%$ of the total cumulative consumer NPV. DOE rulemakings produced 22 product standards, whereas legislation established 49 
product standards. ${ }^{\mathrm{d}}$ Thus, nearly half of the total energy savings result from the 30 percent of the standards adopted by DOE.

Table 4. Cumulative Primary Energy Savings and Cumulative Consumer NPV Through 2010 for all Standards by Source of the Standards

\begin{tabular}{|lccc|}
\hline $\begin{array}{l}\text { Source of } \\
\text { Standards }\end{array}$ & $\begin{array}{c}\text { Cumulative } \\
\text { Primary } \\
\text { Energy } \\
\text { Savings } \\
\text { (quads) }\end{array}$ & $\begin{array}{c}\text { Consumer } \\
\text { NPV at 3\% } \\
\text { discount rate } \\
\text { (billion 2010\$) }\end{array}$ & $\begin{array}{c}\text { Consumer } \\
\text { NPV at 7\% } \\
\text { discount rate } \\
\text { (billion 2010\$) }\end{array}$ \\
\hline Legislation & 10.3 & 93.4 & 124.4 \\
\hline NAECA 1987/1988 & 7.3 & 145.7 & 182.0 \\
\hline EPACT 1992 & 0.6 & 4.9 & 5.1 \\
\hline EPACT 2005 & 0.4 & -2.9 & -3.0 \\
\hline EISA 2007 & 18.6 & 241.1 & 308.5 \\
\hline \multicolumn{1}{|c|}{ Subtotal } & & 28.4 & 32.6 \\
\hline DOE Rulemakings & 7.3 & $\mathbf{2 6 9 . 6}$ & $\mathbf{3 4 1 . 1}$ \\
\hline \multicolumn{1}{c}{ Subtotal } & $\mathbf{2 5 . 9}$ & & \\
\hline Total & &
\end{tabular}

* Impacts in 2010 are very small since the standards are just taking effect.

Table 5. Cumulative Primary Energy Savings and NPV for all Standards by Source of the Standards

\begin{tabular}{|lccc|}
\hline $\begin{array}{l}\text { Source of } \\
\text { Standards }\end{array}$ & $\begin{array}{c}\text { Primary } \\
\text { Energy } \\
\text { Savings } \\
\text { (quads) }\end{array}$ & $\begin{array}{c}\text { Consumer } \\
\text { NPV at 3\% } \\
\text { discount rate } \\
\text { (billion 2010\$) }\end{array}$ & $\begin{array}{c}\text { Consumer } \\
\text { NPV at 7\% } \\
\text { discount rate } \\
\text { (billion 2010\$) }\end{array}$ \\
\hline Legislation & & & \\
\hline NAECA 1987/1988 & 21.3 & 166.6 & 176.7 \\
\hline EPACT 1992 & 15.3 & 309.9 & 307.9 \\
\hline EPACT 2005 & 15.5 & 99.3 & 61.2 \\
\hline EISA 2007 & 30.7 & 113.0 & 59.2 \\
\hline \multicolumn{1}{|c|}{ Subtotal } & 82.8 & 688.8 & 604.9 \\
\hline DOE Rulemakings & & & \\
\hline \multicolumn{1}{|c|}{ Subtotal } & 75.0 & 413.8 & 245.6 \\
\hline Total & $\mathbf{1 5 7 . 9}$ & $\mathbf{1 1 0 2 . 6}$ & $\mathbf{8 5 0 . 5}$ \\
\hline
\end{tabular}

Table 6 presents the annual and cumulative water savings from standards. The results include water savings from water conservation standards as well as from energy conservation standards that also save water (such as standards on clothes washers and dishwashers). ${ }^{\mathrm{e}}$ The annual savings

\footnotetext{
${ }^{\mathrm{d}}$ By "product standard" we mean the set of standards associated with the products listed in Table 1. Within each of these general product categories, there are numerous specific standards for the various product classes.

${ }^{\mathrm{e}}$ Note that water savings estimates are not available for commercial plumbing products (water closets, urinals, and faucets).
} 
of 1.5 trillion gallons in 2010 are equal to 9 percent of the total water withdrawals for public supply in $2005 .^{\mathrm{f}}$

Table 6. Annual and Cumulative Water Savings for All Water-Conserving Standards

\begin{tabular}{|lcc|}
\hline & \multicolumn{2}{c|}{ Water Savings (trillion gallons) } \\
& Annual & Cumulative through \\
\hline $\mathbf{2 0 1 0}$ & 1.5 & 11.7 \\
\hline $\mathbf{2 0 2 5}$ & 1.5 & 38.6 \\
\hline $\mathbf{2 0 4 0}$ & 0.3 & 51.4 \\
\hline
\end{tabular}

As shown in Table 7, the estimated reduction in $\mathrm{CO}_{2}$ emissions associated with the standards in 2010 was 167 million metric tons of $\mathrm{CO}_{2}$, which amounts to $3.0 \%$ of total U.S. $\mathrm{CO}_{2}$ emissions in 2010. The estimated economic value of all reductions in $\mathrm{CO}_{2}$ emissions associated with the standards is more than $\$ 182$ billion.

Table 7. Annual and Cumulative Reduction in Carbon Dioxide Emissions for All Energy Conservation Standards

\begin{tabular}{|ccccc|}
\hline & $\begin{array}{c}\mathbf{C O}_{2} \text { Emissions Reduction } \\
\text { (million tons } \mathbf{C O}_{2} \text { ) } \\
\text { Cumulative } \\
\text { through }\end{array}$ & $\begin{array}{c}\text { Present Value } \\
\text { (billion 2010\$) }\end{array}$ \\
Annual & Annual & $\begin{array}{c}\text { Cumulative } \\
\text { through }\end{array}$ \\
\hline $\mathbf{2 0 1 0}$ & 167 & 1544 & 5.0 & 51 \\
\hline $\mathbf{2 0 2 5}$ & 262 & 5158 & 5.0 & 131 \\
\hline $\mathbf{2 0 4 0}$ & 102 & 8156 & 1.0 & 177 \\
\hline $\mathbf{2 0 5 5}$ & 9 & 8658 & 0.1 & 182 \\
\hline
\end{tabular}

* The present value was calculated using a discount rate of $3 \%$, in keeping with the method used by DOE in recent rulemakings. See discussion in appendix A.

Figure 1 shows the annual primary energy savings for each grouping of standards, and Figure 2 shows the annual undiscounted net consumer impact. The impacts will peak in the 2020-2025 period as purchases of products subject to standards increase. The decline in impacts reflects the analytical convention used to count impacts for 25-30 years of shipments for each standard. The annual savings peak at around $\$ 48$ billion in the 2020-2025 period.

\footnotetext{
${ }^{\mathrm{f}}$ USGS estimates that water withdrawals for public supply were $44.2 \mathrm{Bgal} / \mathrm{day}$ in 2005 . http://pubs.usgs.gov/circ/1344/
} 


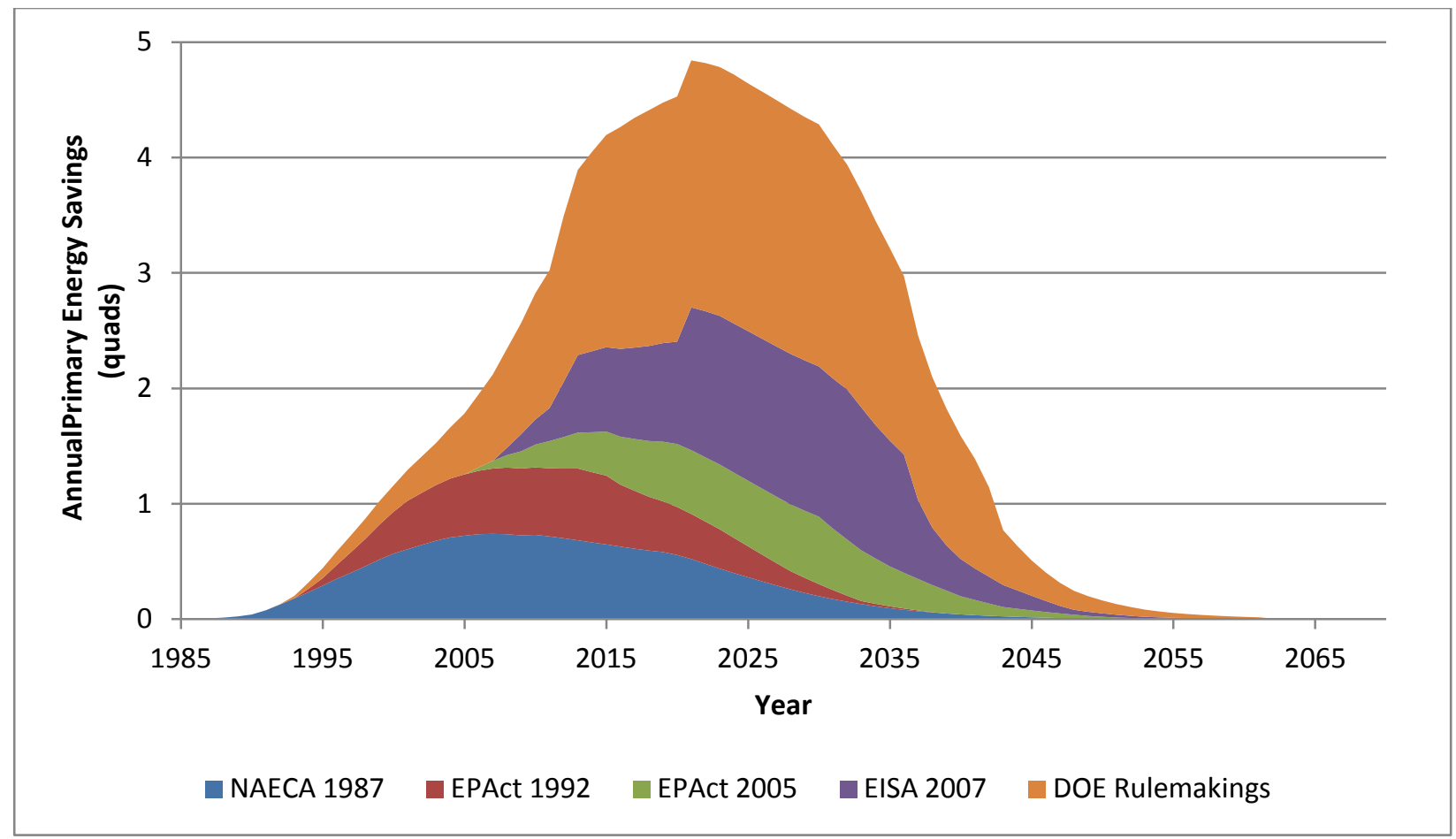

Figure 1. Annual Primary Energy Savings for all Standards by Source of the Standards

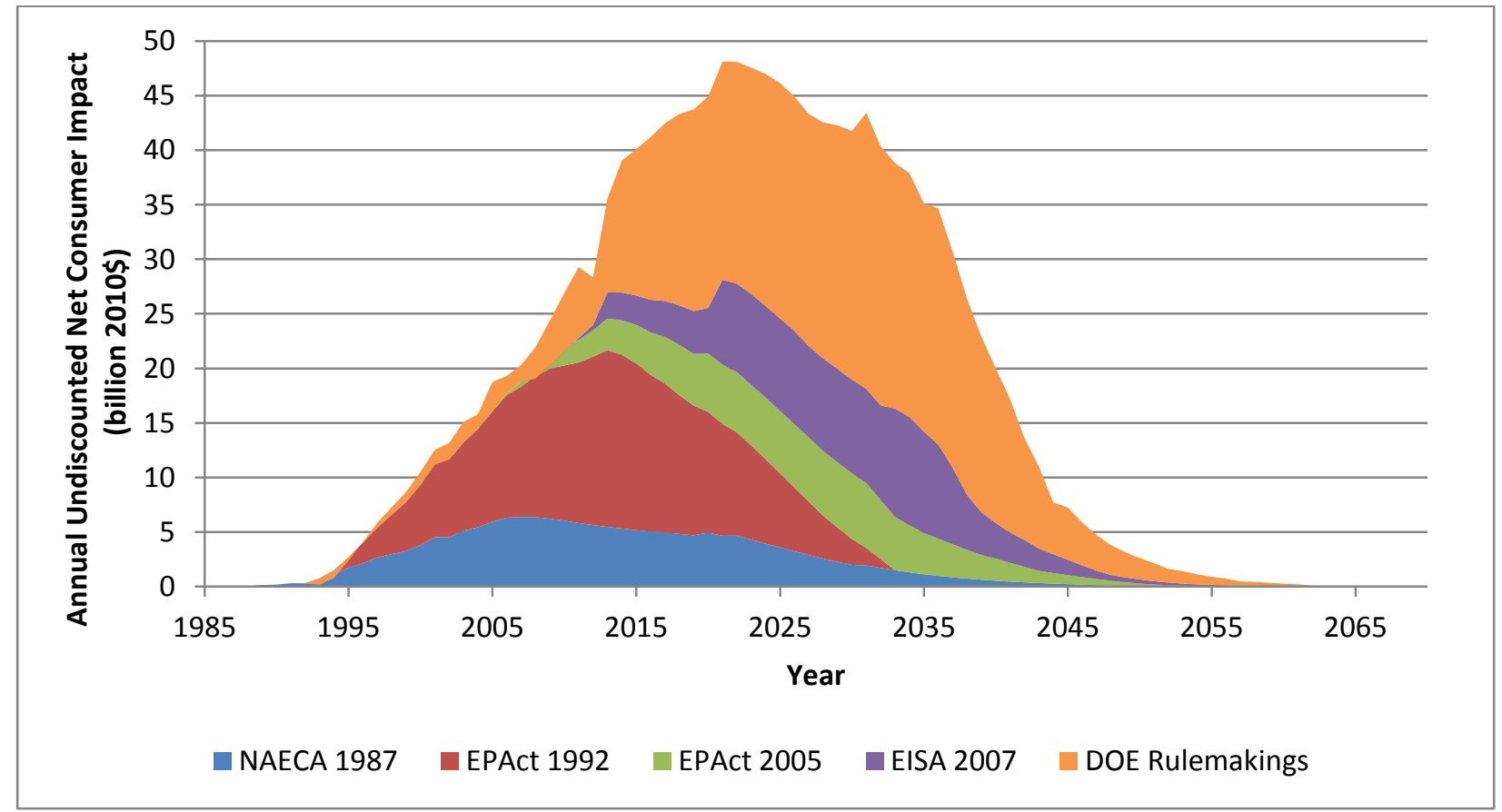

Figure 2. Annual Undiscounted Net Consumer Benefit for all Standards 
Figure 3 illustrates how standards have had an important effect on the energy efficiency of new products, in this case refrigerator-freezers. The average new refrigerator-freezer in 2010 used only $44 \%$ of the energy per year as an average new unit in 1985. Total energy use for these products has declined even as shipments increased and the average size of new units grew. Nationally, in 2010 refrigerator-freezers used one-third less total energy than in 1985 even though there were 70 million more units in use. ${ }^{\mathrm{g}}$

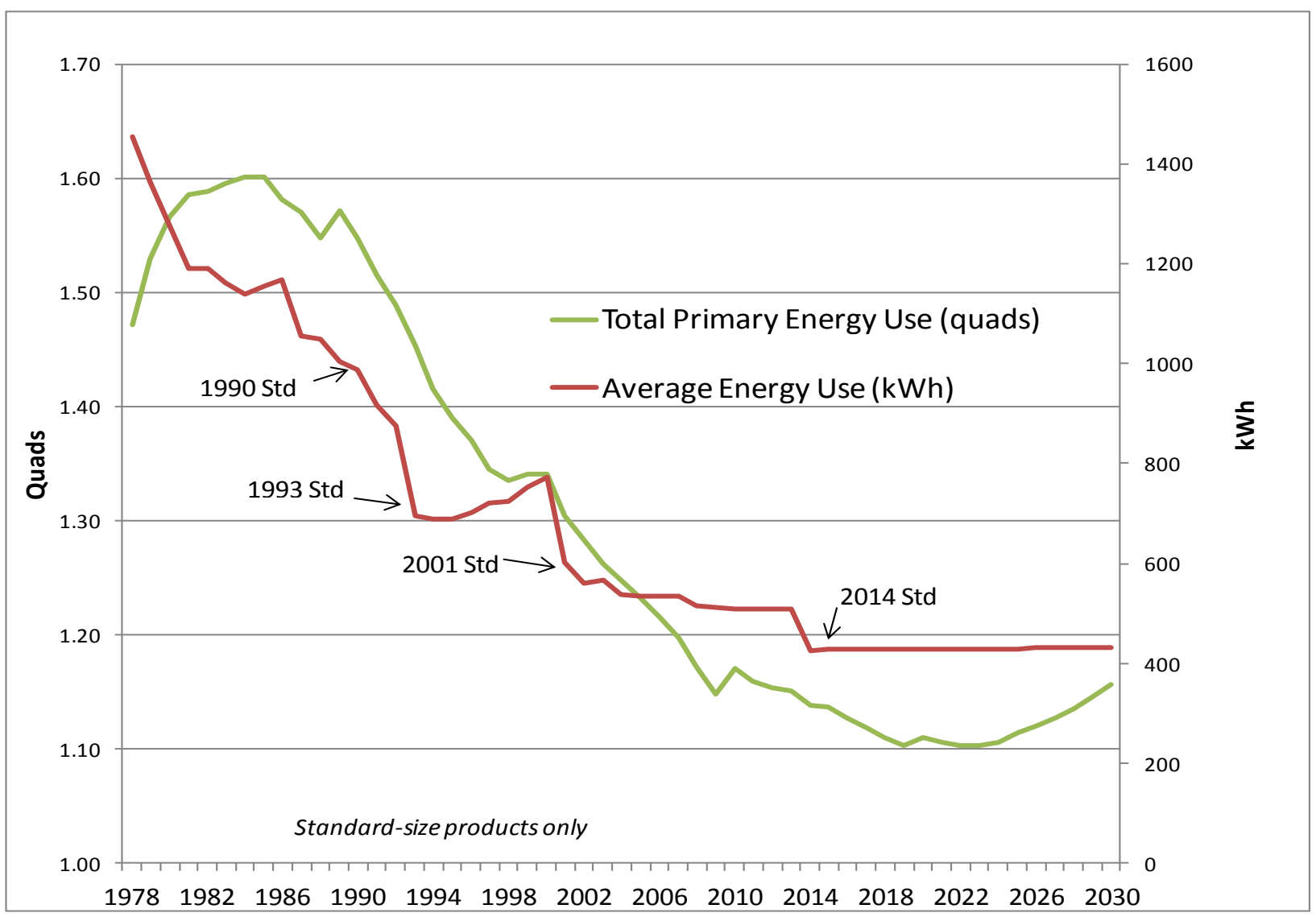

Figure 3. Refrigerator-Freezer Energy Use Trends: Average Energy Use for New Products and Total Energy Use for Refrigerator-Freezers

Source: AHAM Fact Books and 2011 DOE standards rulemaking for residential refrigeration products. ${ }^{\text {h }}$

\section{Consumer Impacts}

In 2010, we estimate that the typical household is saving approximately $\$ 175$ as a result of standards. By 2010, most U.S. households used one or more appliances that were subject to Federal energy or water conservation standards. On average, the primary energy savings from

\footnotetext{
${ }^{\mathrm{g}}$ The increase in total energy use depicted after 2025 is due to growth in purchases of refrigerator-freezers. If the standard is updated as required by EPCA, the declining trend would continue.

${ }^{\mathrm{h}}$ http://www1.eere.energy.gov/buildings/appliance_standards/pdfs/refrig_finalrule_tsd.pdf
} 
residential standards in 2010 amounted to 16 million Btu per household, which is equivalent to 8.6 percent of the total energy use of 186 million Btu.

\section{Sources of Uncertainty}

The estimates made by this study are subject to considerable uncertainty. A major source of uncertainty is the assumed base case against which the impacts of standards are measured. In principle, a base case should reflect best judgment as to how the market for a given product will evolve without the standards under consideration. Estimating the consumer demand for higher efficiency products is difficult. Even more difficult is estimating what other policies, either Federal or State, might be implemented if there were no Federal standards.

We have more confidence in the estimates of per-unit energy savings and additional cost in the sources used for this study, though these too are subject to uncertainty. All of the sources assume that the incremental costs of higher efficiency remain constant over time. This assumption likely overstates the true costs for two reasons. First, manufacturers of appliances and equipment often find ways to reduce the cost of producing higher efficiency products. Second, inflation-adjusted prices of many types of appliances and equipment have trended downward in recent decades. To the extent that this trend continues, it means that the incremental cost of higher efficiency products may decline over time.

The estimates of primary energy savings in the sources we used are based on estimates of "site" energy savings (i.e., savings where the product is in operation). Most of the sources convert site savings to primary savings using an average multiplier. In contrast, the National Impact Analysis spreadsheets from the DOE rulemakings incorporate marginal site-to-source energy conversion factors. These factors represent the response of the electricity system to an incremental decrease in consumption associated with appliance standards. DOE uses annual site-to-source conversion factors based on a version of the Energy Information Administration's National Energy

Modeling System (NEMS). The marginal factors are lower than average site-to-source conversion factors and are likely more accurate. If we had been able to apply marginal site-tosource conversion factors to all of the standards included, the estimated primary energy savings (and also the reductions in $\mathrm{CO}_{2}$ emissions) would be lower.

For consumer cost savings that occurred in the past, there is some question as to whether the compounding of past savings used in this study is appropriate. We have not found clear guidance in the literature, but there is some precedent for the practice of compounding past savings to estimate their present value. ${ }^{\text {i }}$ There is uncertainty regarding the extent to which the savings from appliance standards were invested elsewhere in the economy, and what the appropriate interest rate should be. Without compounding, the cumulative consumer NPV for all standards through 2010 would be around 15 percent less.

\footnotetext{
'See for example: http://www.dalemarsden.ca/docs/publications/Marsden_etal_2006.pdf
} 
There is some evidence that consumers use higher efficiency appliances more intensively due to the reduction in operating cost. The extent of this so-called direct rebound effect varies among products. ${ }^{5}$ In recent years DOE has accounted for a rebound effect in many of its rulemakings. Thus, the energy savings estimates for many standards in the DOE 2007-2010 grouping include an adjustment (subtraction) for a rebound effect. ${ }^{j}$ The other sources used for this study do not include such an adjustment. The lack of this adjustment means that the savings may be overestimated by $5 \%-10 \%$.

\section{Conclusion}

We estimate that energy efficiency standards for residential appliances and commercial equipment that have been adopted from 1987 through 2010 have saved a total of 26 quads, an amount equal to one-fourth of total U.S. energy use in 2010. The cumulative consumer operating cost savings minus additional product costs associated with standards, through 2010, is between $\$ 270$ billion and $\$ 341$ billion.

Energy efficiency standards have benefitted U.S. consumers across the country. By 2010, most U.S. households used one or more appliances that were subject to Federal energy or water conservation standards. On average, the primary energy savings from residential standards in 2010 amounted to 16 million Btu per household, which is equivalent to 8.6 percent of the total energy use per household.

The majority of the savings attributable to all the standards adopted thus far are still to come, as products subject to the standards enter the stock. The standards will achieve cumulative energy savings of 158 quads, and will have a cumulative present value of consumer benefit of between $\$ 851$ billion and $\$ 1,103$ billion. In addition, the standards will reduce water use and provide other environmental benefits, such as decreases in emissions of carbon dioxide and nitrogen oxides.

\footnotetext{
${ }^{\mathrm{j}}$ DOE does not adjust the energy cost savings for the rebound effect because it believes that, if it were able to monetize the increased value to consumers associated with the rebound effect, this value would be similar to the foregone energy savings.
} 


\section{Appendix A: Methods for Estimating National Impacts from Standards ${ }^{k}$}

\section{NAECA 1987 and 1988 and DOE Updates before 2007}

For all of the standards except one, we used the data developed by Meyers et al. ${ }^{1}$ That study developed a spreadsheet accounting model to calculate energy savings and consumer costs and savings for each product. The model tracks the energy use of products sold in each year, beginning in the late 1980s. The model uses historic and projected data on annual shipments of each product and subtracts units from the stock using a retirement function based on the estimated average lifetime of each product.

The key feature of the model is that it associates a specific average energy consumption and average product price for each vintage of a given product. (A vintage refers to the products shipped in a given year.) Both of these variables are a function of the energy efficiency assigned to each vintage. In most cases, the actual energy efficiency for each vintage of a product is assigned based on industry sources.

The approach for estimating the impacts of standards involves deriving a base case scenario for average energy efficiency and product price that assumes no standards were or will be implemented. In principle, the base case assumes energy efficiency increases over time as a result of all factors that shape energy efficiency other than Federal standards. For further discussion, see section 2 of Meyers et al.

For the commercial heating, air conditioning, and water heating standards with compliance dates of 2003 and 2004, we started from the following data reported by Belzer and Winiarski: ${ }^{6}(1)$ primary energy savings cumulative through 2030 and (2) net economic impacts at a 7-percent discount rate cumulative from units shipped through 2030. We used an average lifetime for these products of 15 years.

We assume that units retire uniformly over the lifetime and that the annual energy savings will go up after the effective date until it stabilizes when all the pre-standard units have been replaced by units meeting the standards. This period that it takes for the annual energy savings to reach its maximum is equal to the lifetime of the product. Using these assumptions, we calculate the annual site and primary energy savings that will match the given cumulative energy savings from 2003 to 2030. Then we used the Excel Solver to solve for the unit energy saving and incremental equipment cost per unit that will give a net present value (NPV) that closely matches the given NPV at a 7-percent discount rate. We then extended the time series to include shipments through 2032 to yield a 30-year analysis period.

\footnotetext{
${ }^{k}$ Further details are given in cell comments in the Excel spreadsheet used to calculate the impacts, which may be found at the page for this report at: http://efficiency.lbl.gov/bibliography/
} 


\section{EPACT 1992}

We developed new estimates for this study, as described below. We assumed no change in base case efficiency over time. To compensate for potential overstatement of savings, we counted impacts for only 20 years worth of product shipments. Further details may be found in spreadsheets that are available from the authors.

Commercial furnaces and boilers, air conditioners and heat pumps, and water heaters We modified the analytical structure and some of the data developed by Rosenquist et al. for the 2004 study for the National Commission on Energy Policy (NCEP). ${ }^{7}$

We estimated base case efficiencies and unit incremental costs for these products using PNNL (2000). This report presents average efficiencies in 1999 and costs for both an EPACT 1992 baseline product and an average product in 1999. We applied these differentials to derive an approximate pre-EPACT 1992 baseline efficiency and contractor cost for each product.

\section{Electric motors}

We developed a simplified NIA model to estimate the impacts of the EPACT 1992 standards for electric motors, using one "average motor" as the basis for the calculations.

The "average motor" energy use was calculated in the base case and in the standards case, using market-weighted averages across the covered horsepower (hp) ranges, pole configurations, and enclosure type to determine the following parameters: operating hours, load, lifetime, horsepower, and efficiency. All inputs were derived from the draft preliminary analysis from DOE's 2011 rulemaking for electric motors.

The base-case efficiency is estimated assuming 30\% of shipped motors are at pre-EPACT standard efficiency levels, 30\% are already at the EPACT 1992 efficiency levels, and 40\% are at National Electrical Manufacturers Association (NEMA) premium efficiency levels. The standards-case efficiency is estimated using a "roll-up" scenario, which leads to assuming $60 \%$ of motors are at the EPACT 1992 efficiency levels and 40\% are at the NEMA premium efficiency levels.

Motor equipment costs (includes the repair costs) for the "average motor" in the base case and standards case were estimated by extrapolating price and weight data from the preliminary analysis. Repairs are assumed to occur after 5 years of usage and once in a motor's lifetime.

Shipment data were obtained from the preliminary analysis and are assumed to be the same in the base-case and in the standards-case. The market-weighted average lifetime (12 years) was used to calculate the affected stock.

National site energy savings were obtained from multiplying the affected stock by the difference in energy use between the base case and standards case for the "average motor". National 
equipment incremental costs were calculated using the affected stock multiplied by the difference in equipment costs between the base case and standards case for the "average motor".

\section{Fluorescent lamps and incandescent reflector lamps}

\section{Fluorescent lamps}

We calculated savings for full-wattage T12 lamps covered by the standards sold after the effective dates of the standards: April 30, 1994 for 8-foot T12 and 8-foot T12/HO lamps and October 31, 1995 for 4-foot lamps. To calculate fluorescent lamp shipments, we adapted the spreadsheet used to analyze the impacts of the NAECA fluorescent ballast standards by Meyers et al. The base-case forecast assumed that 60 percent of lamp shipments in 1994 were fullwattage lamps, while 40 percent were reduced-wattage lamps already complying with the EPAct 1992 standards, according to a 1989 report on Massachusetts' lamp standards by Nadel et al. ${ }^{8}$

Since the lamps covered by the EPAct 1992 lamp standards ("covered lamps") were used with magnetic ballasts, with very few T12 lamps used with electronic ballasts, we assumed that lamp shipments tracked the pattern of magnetic ballast shipments. When the fluorescent ballast standards came into effect in 2005 for ballasts in new luminaires, there was a corresponding substantial decrease in T12 lamp shipments. By 2010, when the ballast standards took effect for the renovation market as well, very few T12 lamps were sold (in the commercial/industrial market).

The shipments of covered fluorescent lamps for 1994 were based on estimates by Geller and Nadel. ${ }^{9}$ For 1995 - 2010 we scaled this 1994 shipment value to decline according to the annual decrease in magnetic ballast shipments projected in the NAECA ballast standards analysis. Beginning in 2011 we made the simplifying assumption that T12 lamp shipments ceased.

Assumptions for unit wattage savings, product service lifetime, operating hours, and market shares by lamp type and by new vs. renovation market are from DOE's 2000 fluorescent lamp ballast standards analysis. Lamp prices are from the 1992 Lighting Policy Analysis by Atkinson et al. ${ }^{10}$

\section{$\underline{\text { Incandescent reflector lamps }}$}

We estimated the impacts of the incandescent reflector lamp standards from 1996 - 2015. (The standards took effect on November 1, 1995, so we assumed that savings began in 1996.) We used shipments data from past and recent analyses to estimate the annual shipments of lamps complying with the standards. For the commercial sector, complying shipments were derived for 1996 - 2000 from the 1992 Lighting Policy Analysis (Atkinson et al.), for 2006 - 2015 from DOE's 2009 incandescent reflector lamp standards NIA spreadsheet (DOE 2009), ${ }^{1}$ and for 2001

'See: 
- 2005 by linear interpolation. For the residential sector, we estimated complying shipments for 1995 as 10 percent of total shipments, for 2001 - 2015 from DOE 2009, and for 1996 to 2000 by linear interpolation.

Assumptions for unit wattage savings are from Atkinson et al. Product service lifetime and operating hours are from DOE 2009. Lamp prices are from Atkinson et al.

\section{Plumbing products}

For showerheads and faucets, we started with product lifetime, 2010 site energy savings (from reduced hot water use), and 2010 water savings from Koomey et al. ${ }^{11}$ For toilets, we used product lifetime and 2010 water savings.

From the energy savings for 2010, we estimated both the site and source energy savings over a 20-year period starting from the compliance date, assuming that shipments retire uniformly over the lifetime and are replaced (constant annual sales). Based on this uniform retirement function, the energy savings from units surviving beyond the 20 -year period are also calculated. We performed this same estimation for the annual time series of water savings.

We derived operating cost savings by applying annual time series of average fuel prices and water prices to the site energy and water savings.

We estimated that there is zero unit incremental cost for these products because, when manufacturers first started to comply with EPACT 1992, they generally did not make significant changes to the products.

The estimates only cover residential use because no data were available to estimate commercial sector impacts.

\section{EPACT 2005}

For all of the standards except commercial air conditioners (AC) and heat pumps, we started from the following data reported by Nadel et al. ${ }^{3}$ for each standard: (1) site energy savings in 2020 and 2030, (2) cumulative energy savings through 2030, (3) NPV for products sold through 2030, (4) lifetime, (5) unit annual energy saving, and (6) unit incremental equipment cost. Nadel et al. used a constant efficiency base case, but they also did not model any increase in shipments; these two factors would counteract to some extent.

From the energy savings for 2020 and 2030, we estimated both the site and source energy savings for 25 years of shipments starting from the compliance year. Using the energy savings per unit and the annual energy savings, we calculated the shipments in each year. Once we derived the shipments, we could calculate the total incremental equipment cost.

http://www1.eere.energy.gov/buildings/appliance_standards/residential/incandescent_lamps_standards_final_rule_to ols.html 
We accounted for impacts to shipments through 2030. The number of years of shipments ranges from 21 to 25 , depending on the particular standard.

For commercial AC and heat pumps, DOE National Impact Analysis spreadsheets were available. For these products, we followed the methods described in the DOE Standards 20072010 section.

\section{EISA 2007}

For most EISA 2007 standards, we started from the following data for each product reported by DOE in its technical report: ${ }^{4}$ (1) cumulative energy savings (through 2038), (2) NPV at 3-percent and 7-percent discount rates. From other relevant DOE sources, we obtained the lifetimes of the products. The DOE report used a constant efficiency base case, which may tend to somewhat overestimate the savings from the standards. To compensate, we used 25 years of shipments instead of 30 years.

We assumed that units retire uniformly over the lifetime and that the annual energy savings will go up after the compliance date until it stabilizes when all the pre-standard units have been replaced by units meeting the standards. The period that it takes for the annual energy savings to reach its maximum is equal to the lifetime of the product. Using these assumptions, we calculated the annual site and source energy savings that will match the given cumulative energy savings. Then we used the Excel Solver to solve for the unit energy savings and incremental equipment cost per unit that will give an NPV that closely matches the given NPV at a 7-percent discount rate. We then adjusted the calculations to account for 25 years of shipments.

For a few EISA 2007 standards (residential boilers, dishwashers, and dehumidifiers), DOE National Impact Analysis spreadsheets were available. For these products, we followed the methods described in the following DOE Standards 2007-2010 section.

\section{DOE Standards 2007-2010}

We used the Final Rule NIA spreadsheets from the DOE rulemakings for each of these standards. We set up the spreadsheets for the compliance year and standard levels that were selected in the Final Rules. This gave the annual time series desired: primary energy savings, additional installed cost, and operating cost savings. In some cases, the time series presented in the spreadsheets were by individual product classes, so we summed them to arrive at totals for the product category or categories in question. In some cases we also made modifications to the spreadsheets to arrive at consistent results across products-for instance, always using 30 years of shipments and extending energy cost savings and energy savings to the end of the lifetime of the units shipped in the $30^{\text {th }}$ year. ${ }^{\mathrm{m}}$

\footnotetext{
${ }^{m}$ This accounting approach differs from what DOE reports in its rulemakings, in which DOE presents energy savings over a 30 -year period.
} 


\section{General Methods}

We converted dollars from the year given in the various sources to $2010 \$$ using the Consumer Price Index for residential appliances and the GDP implicit price deflator for commercial and industrial equipment.

The annual average $\mathrm{CO}_{2}$ emissions factors for the electricity generation sector are derived for each year through 2008 from EIA statistics on total $\mathrm{CO}_{2}$ emissions from the electric power sector and total primary energy consumption by the electric power sector and, for each year after 2008, are derived from similar forecasted outputs in EIA's Annual Energy Outlook 2011.

The SCC values are from the mid-range series developed by an interagency process. This series is based on the average SCC derived from the three integrated assessment models that were examined, using a 3-percent discount rate.n Because the SCC values are based on a 3-percent discount rate, we used the same discount rate to discount the future annual estimates of the value of reduced $\mathrm{CO}_{2}$ emissions.

\footnotetext{
${ }^{\mathrm{n}}$ For more information on these SCC values, see chapter 16 and appendix 16-A of the Residential Clothes Dryers and Room Air Conditioners Direct Final Rule Technical Support Document.

http://www1.eere.energy.gov/buildings/appliance_standards/residential/residential_clothes_dryers_room_ac_dir ect_final_rule_tsd.html
} 


\section{Appendix B: Quad and Carbon Equivalents}

From the U.S. Department of Energy's 2010 Buildings Energy Data Book.

1.5.1 Key Definitions
Quad: Quadrillion Btu (10^15 or 1,000,000,000,000,000 Btu)
Generic Quad for the Buildings Sector: One quad of primary energy consumed in the buildings sector (includes the
residential and commercial sectors), apportioned between the various primary fuels used in the sector according to their relative
consumption in a given year. To obtain this value, electricity is converted into its primary energy forms according to relative fuel
contributions (or shares) used to produce electricity in the given year.
Electric Quad (Generic Quad for the Electric Utility Sector): One quad of primary energy consumed at electric
utility power plants to supply electricity to end-users, shared among various fuels according to their relative contribution in
a given year. (Note: The consumption of an electric quad results in the delivery of just under $1 / 3$ the electric quad due to
generation and transmission losses.)
Primary Energy: The total energy consumed by an end-user, including the energy used in the generation and transmission of
electricity. Also referred to as "source" energy.
Delivered Energy: The energy consumed by an end-user on site, not including electricity generation and transmission losses.

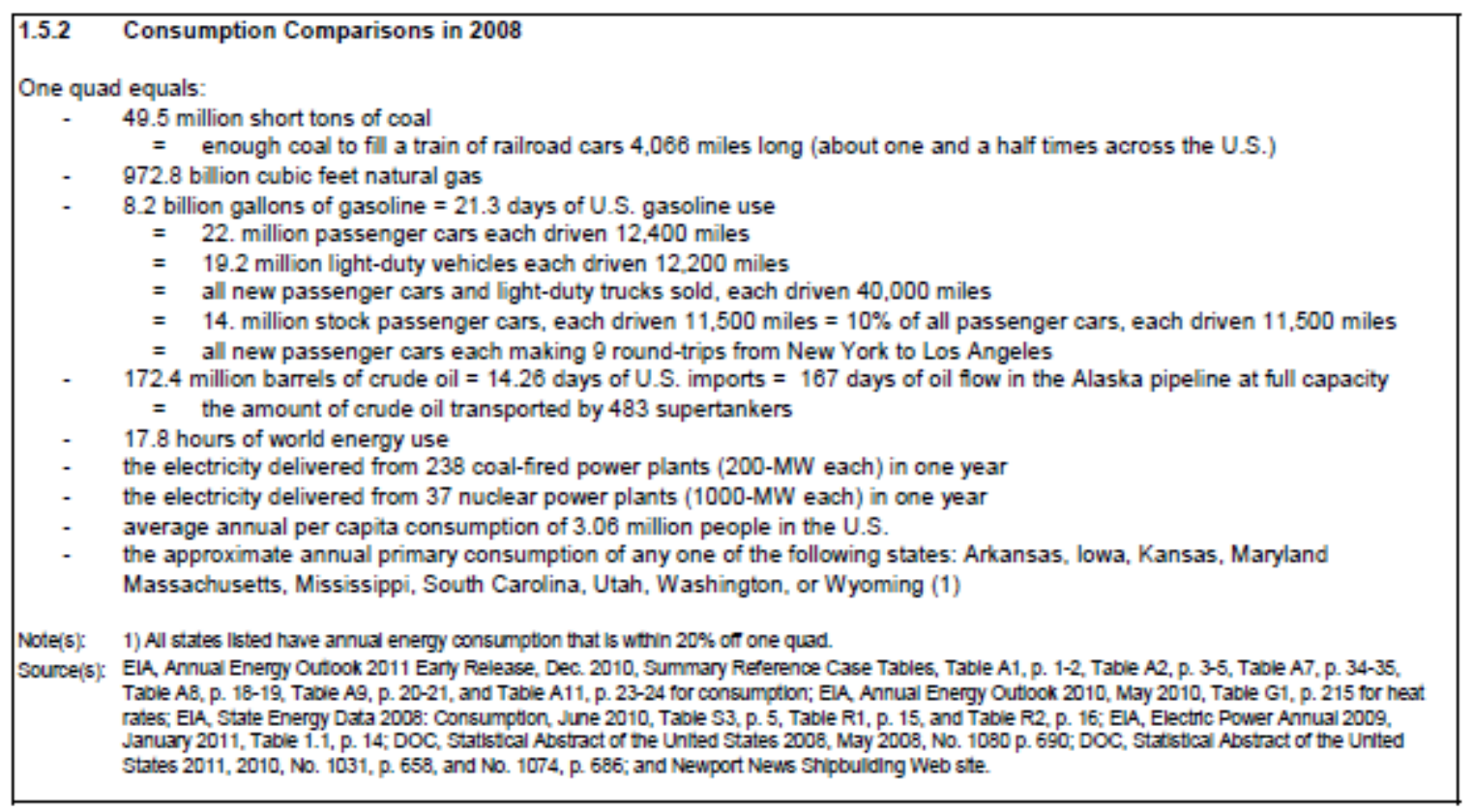




\begin{tabular}{|c|c|}
\hline \begin{tabular}{|l|}
1.5 .3 \\
\end{tabular} & Carbon Emission Comparisons \\
\hline $\begin{array}{c}\text { One milic } \\
- \\
- \\
- \\
\\
\\
\\
- \\
- \\
- \\
- \\
- \\
- \\
- \\
- \\
-\end{array}$ & $\begin{array}{l}\text { on metric tons of carbon dioxide-equivalent emissions equals: } \\
\text { the combustion of } 525 \text { thousand short tons of coal } \\
\text { the coal input to } 1 \text { coal plant ( } 200 \text {-MW) in ten and a half months } \\
\text { the combustion of } 18 \text { billion cubic feet of natural gas } \\
\text { the combustion of } 118 \text { million gallons of gasoline }=\text { the combustion of gasoline for } 7 \text { hours in the U.S. } \\
=\quad 310 \text { thousand new cars, each driven } 12,400 \text { miles } \\
=\quad 272 \text { thousand new light-duty vehicles, each driven } 12,200 \text { miles } \\
=\quad 260 \text { thousand new light trucks, each driven } 11,000 \text { miles } \\
=\quad 0.14 \text { million new passenger cars, each making } 5 \text { round trips from New York to Los Angeles } \\
\text { the combustion of } 190 \text { million gallons of LPG } \\
\text { the combustion of } 107 \text { million gallons of kerosene } \\
\text { the combustion of } 102 \text { million gallons of distillate fuel } \\
\text { the combustion of } 87 \text { million gallons of residual fuel } \\
17 \text { minutes of world energy emissions } \\
90 \text { minutes of U.S energy emissions } \\
3.9 \text { hours of U.S. buildings energy emissions } \\
7 \text { hours of U.S. residential energy emissions } \\
8 \text { hours of U.S. commercial energy emissions } \\
1 \text { day of U.S. buildings lighting energy emissions } \\
\text { average annual per capita emissions of } 52,000 \text { people in the U.S. }\end{array}$ \\
\hline Source(s): & 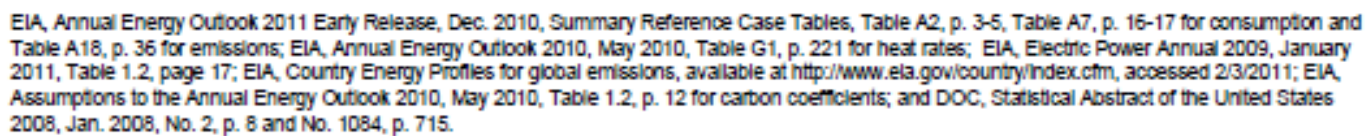 \\
\hline
\end{tabular}




\section{REFERENCES}

1 Meyers, S., J. McMahon, and B. Atkinson. Realized and Projected Impacts of U.S. Energy Efficiency Standards for Residential and Commercial Appliances. LBNL-63017. Lawrence Berkeley National Laboratory, Berkeley, CA. 2008. http://www.osti.gov/bridge/purl.cover.jsp?purl=/938510-IKYBEw/

2 Nadel, S., A. deLaski, J. Kleisch, and T. Kubo. Leading the Way: Continued Opportunities for New State Appliance and Equipment Efficiency Standards. American Council for an EnergyEfficient Economy and Appliance Standards Awareness Project. Washington, DC. January 2005. http://www.aceee.org/sites/default/files/publications/researchreports/a051.pdf

3 TECHNICAL SUPPORT DOCUMENT-Impacts on the Nation of the Energy Independence and Security Act of 2007, March 2009; Available at: http://www1.eere.energy.gov/buildings/appliance_standards/pdfs/en_masse tsd_march_2009. pdf

Office of Management and Budget. OMB Circular A-4, Regulatory Analysis. Washington, D.C. September 17, 2003. www.whitehouse.gov/omb/assets/omb/circulars/a004/a-4.pdf

5 S. Sorrell, J. Dimitropoulos, and M. Sommerville, "Empirical estimates of the direct rebound effect: a review," Energy Policy 37(2009) pp. 1356-71.

6 Belzer, D. and D. Winiarski. EPACT-Covered Commercial HVAC and Water Heating Equipment: Summary of Energy Savings and Economic Benefits - 2004. 11/4/2004. Pacific Northwest National Laboratory.

${ }^{7}$ Rosenquist, Greg, Michael McNeil, Maithili Iyer, Steve Meyers, and Jim McMahon. Energy Efficiency Standards for Equipment: Additional Opportunities in the Residential and Commercial Sectors. Energy Policy 34(2004) pp 3257-3267.

${ }^{8}$ Nadel, S., H. Geller, F. Davis and D. Goldstein. 1989. Lamp Efficiency Standards for Massachusetts: Analysis and Recommendations. June, 1989. American Council for an EnergyEfficient Economy (Washington DC), Fred Davis Corporation (Medfield MA), Natural Resources Defense Council (San Francisco CA). Prepared for Massachusetts Executive Office of Energy Resources. Research Report A891.

${ }^{9}$ Geller, H., and S. Nadel. Consensus National Efficiency Standards for Lamps, Motors, Showerheads and Faucets, and Commercial HVAC Equipment. American Council for an Energy-Efficient Economy. Washington, DC. June 1992. http://www.aceee.org/sites/default/files/publications/researchreports/A921.pdf 
${ }^{10}$ B. Atkinson et al., Analysis of Federal Policy Options for Improving U.S. Lighting Energy Efficiency: Commercial and Residential Buildings. LBL-31469. December 1992. Lawrence Berkeley Laboratory.

${ }^{11}$ Koomey, Jonathan, Camilla Dunham, and James D. Lutz. The Effect of Efficiency Standards on Water Use and Water Heating Energy Use in the U.S.: A Detailed End-use Treatment. LBL35475. Lawrence Berkeley Laboratory. May 1994. 